How to cite: Ilie, N., Apostol, L., Axinte, A.-D. (2020) The Synoptic Conditions Associated to Hail Occurrence in Moldova. 2020 "Air and Water - Components of the Environment" Conference Proceedings, Cluj-Napoca, Romania, p. 81-92, DOI: 10.24193/AWC2020_08.

\title{
THE SYNOPTIC CONDITIONS ASSOCIATED TO HAIL OCCURRENCE IN MOLDOVA
}

\author{
Nicolae ILIE ${ }^{1,2}$, Liviu APOSTOL ${ }^{2}$, Aurel-Dănuț AXINTE ${ }^{1}$
}

DOI: 10.24193/AWC2020_08

\begin{abstract}
Hail represents a phenomenon among other dangerous phenomena. All of these take place in the warm period of the year. Clouds which are able to generate hail's falls are the convective cells. The agricultural sector is the most sensible in the path of hail's falls. Moldova, where the farm sector prevails, is one the most exposed areas to damages generated by hail's falls.

Within the framework of the studied area, seen on atmospherically types movements, the most favorable in the occurrence of hail are those from North-Easterly and NorthWesterly, both in the cyclonic pattern. Linked to them in the time interval studied (2000 to 2018) was recorded a frequency from North-East in the cyclonic mode (NEC) by $22.7 \%$. Next, the North-Westerly air-mass movements in a cyclonic way (NVC) were about $21.8 \%$. Significant weights were also during South-Westerly cyclonic (SVC) with $16.8 \%$ and Westerly cyclonic (VC) with $11.8 \%$, respectively. The Westerly air-mass movements with its subdivisions (South-Westerly and North-Westerly) are those who generate the most severe convective developments. As a result, the North-Westerly airmasses movements in the cyclonic pattern are those who produced throughout time, the most significant dimensions of hail. In this study, we found that the sizes of hail during North-Westerly movements were between 40 and $60 \mathrm{~mm}$ in diameter.

As a frequency, the most favorable period with hail at the ground's level is valuable in May (29.4\%), followed by June (26.1\%), and July (21.8\%).
\end{abstract}

Keywords: hail, convective cells, cyclonic pattern, Moldova region.

\section{INTRODUCTION}

Hail represents a hydrometeor with very high disruptive potential, especially in the agricultural field (Zao et al., 2015; Changnon et al., 1978; Velten et al., 2015). In the present situation, when we talk about global warming, the disruptive and the frequency of hail will increase (Botzen et al., 2010; Hoogewind et al., 2017). So, with all of those processes linked by global warming, the energetic potential of the convective processes will be higher. In such situations, the hail's dimensions will

\footnotetext{
${ }^{1}$ S.C. INTERVENȚII ACTIVE ÎN ATMOSFERĂ S.R.L. Str. Răcari, Sect. 3, 031828, Bucharest, Romania.nyycu87@yahoo.com; dan.axinte@yahoo.com

${ }^{2}$ University 'Alexandru Ioan Cuza' Carol I ${ }^{\text {st }}$ Av. 700505, Iași, Romania. apostolliv@yahoo.com
} 
increase (Brimelow et al., 2017). Making a study showing the hail's impact over crops represents an important step to take the most appropriate decisions to diminish or remove the risk generated by hail falls (Fuchs et al., 2012).

At the level of Romania, as in all areas from the Northern Hemisphere with a high potential of hail's occurrence, the most favorable conditions are met during the warm period of the year. The high intensity of the convective processes, which are linked with hail formation, is the last month of the spring - May and June, respectively, July (Cică et al., 2015)

Now, at the level of Romania has been elaborated a hail's climatology, exclusively based upon the records made over this hydrometeor on the weather stations' platforms. The analyses on this phenomenon are found in The Climate of Romania (2008).

For values, more credible by interest will be the RADAR products. Those will offer better coverage on the national scale. They are mentioning the fact that based upon those materials; it can be possible to monitor the hail into the maximum reflectivity of the convective cloud. To make as homogenous records of hail falls, by interest, will be to build a network of hail pads. The distance between those devices is five $\mathrm{km}$. The similarity between RADAR and hail pads' results can offer a clearer perspective over the hail's evolution between the maximum reflectivity of the convective clouds and ground. So, in the future, if that technology will be implemented, we can elaborate a variety of coefficients. Those coefficients will be able to show the melting speed of hail between $0^{\circ} \mathrm{C}$ isotherm and ground.

Moldova, through its geographical position, is exposed to the hail's occurrence. The Carpathian range, especially the Wooden Carpathian (Ukraine) and the Eastern Carpathian (Romania), make possible the cold air-mass advection over those areas. In front of this advection there was a warm and moist air-mass. The cold air-mass replaces the previously air-mass when taking place the most intensive convective processes which, also, generate hail falls. From the available records at the regional level, on average, are recorded 0.8 to 1.2 days with hail at the ground's level (Apostol and Machidon, 2009).

\section{DATA AND METHODS}

For this study, as the database we used the dimensions of hail recorded at Bacău, Botoșani, Piatra Neamț, Suceava, Târgu Neamț, and Vaslui. The data about the meteorological parameters took into discussion were available for 2000 to 2018 time interval.

In parallel with the data which I had, it wished a correlation of those data with the synoptically pattern when occurred the hail falls. In doing so, were analyzed all of the days when occurred the hail falls. Associated with that was established a characteristic synoptically pattern. To find the baric topography it followed the synoptically pattern at the $1000 \mathrm{hPa}$ and $500 \mathrm{hPa}$ highs (fig.1). Because we took into account the atmospherical instability, by interest were the cyclonic patterns. As a result, were obtained the following situations: NC, NEC, EC, SEC, SC, SVC, VC, and NVC. Concretely, was taken into account the cardinal point with the 
dominant air-mass movements and the cyclonic pattern noted with 'C.' To separate between cyclonic and anticyclonic patterns, based on the map with the geopotential field, it was followed the $1015 \mathrm{hPa}$ isobar at the level of $1000 \mathrm{hPa}$ geopotential and $552 \mathrm{hPa}$ at $500 \mathrm{hPa}$ geopotential. All the values smaller than $1015 \mathrm{hPa}$, respectively, $552 \mathrm{hPa}$, was associated with the cyclonic pattern.

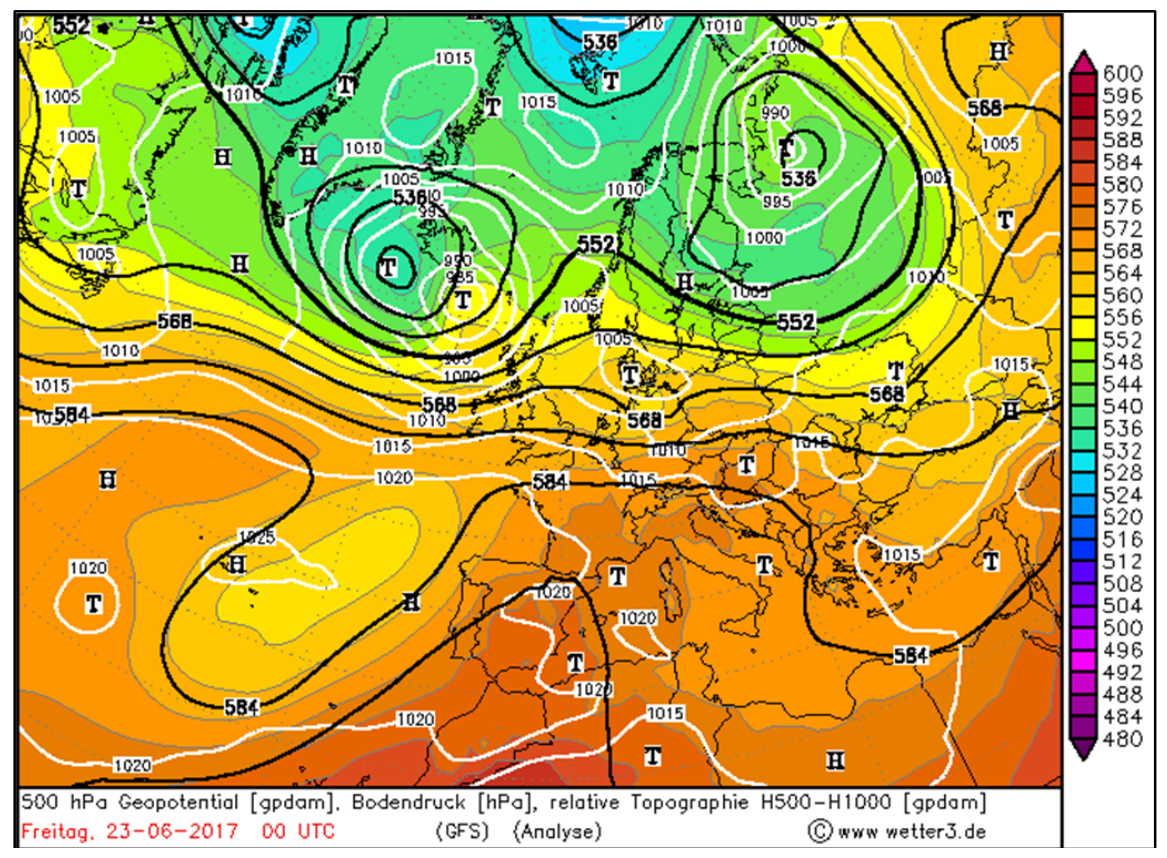

Fig. 1. Map with the baric topography at $1000 \mathrm{hPa}$ height (marked with white isobars) and at 500 hPa height (marked with colors). Source of map: www.wetter3.de/Archive

\section{RESULTS AND DISCUSSIONS}

At the level of Moldova, the most representatives air-mass movements who generating hail falls were those from north-eastern in the cyclonic regime (NEC), with a weight of over $22 \%$ (fig.2). That type of air-mass movement, associated with the retrogressive cyclones, brings notable episodes of atmospherical instability. All of these clouds are associated with high amounts of rain and hail fall. On this atmospherical pattern, the hail's dimensions aren't high; scarcely, the hail reaches the ground. Moreover, at the west are placed in the Eastern Carpathian range. As a result, the eastern slopes of them situated perpendicularly to the clouds' movements - this fact leading to a surplus of precipitations amount, especially into the Pre-Carpathians areas.

Based on those analyzed, in the wake of such air-mass movements, as well as from eastern and south-eastern, both of them in the cyclonic regime, by interest, is the high amount of precipitations that generate massive floods. 
Another representative air-mass movement at Moldova's level who generate hail falls is that from north-western in the cyclonic pattern (NCV), with weights by $21.8 \%$. In contrast with previously, this shows an essential interest for Hail Suppress Unit 'Moldova 1' Iași. On this atmospherically air-mass movement, we can speak by the classical pattern of warm air-mass replacement by one cold, associated with a cold front (Sfîcă et al., 2015). In conditions like this, the updrafts and downdrafts show one of the highest speeds.

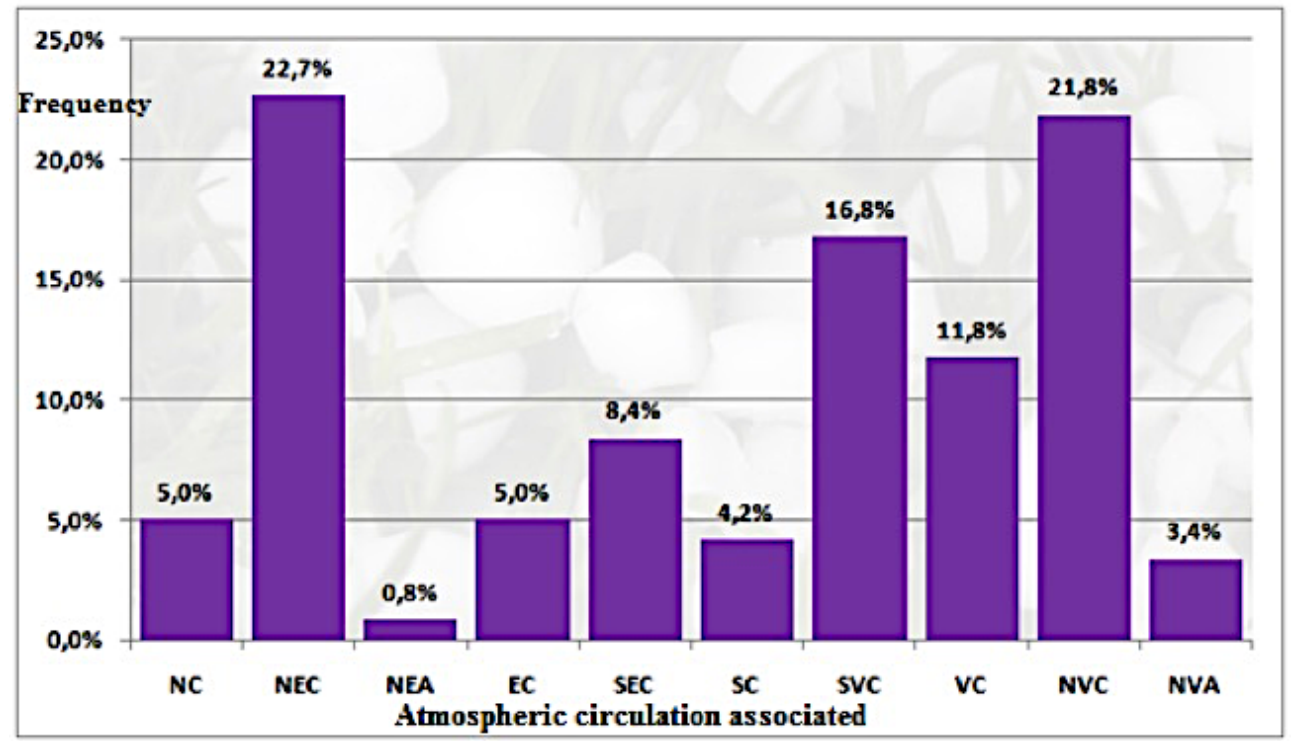

Fig. 2. Frequency of air-mass movement type at the level of Moldova between 2000 and 2018

As a result, there are the most favorable conditions for developing the most significant dimensions of hail. In such patterns was recorded hail with 40 to $60 \mathrm{~cm}$ on diameter at the ground's level. Also, the same air-mass movement is associated with the most disruptive storms, with strong winds which can reach speeds around 25 to $30 \mathrm{~m} / \mathrm{s}$, and downpours.

Also, by interest are the westerly and south-westerly air-mass movements into the cyclonic pattern. Those show the same characteristics as that from north-westerly.

Upon the analyses made, the third weight is owned by south-westerly air-mass movements, also, in the cyclonic pattern (SVC), with $16.8 \%$. This pattern is a south-westerly air-mass movement upon a warm sector of low-atmospherically depressions which are active over the western and north-western part of Europe. In this case, toward Moldova area is carried a warm and moist air-mass from the northern part of Africa, over the central sector of the Mediterranean Sea.

In the frame of such air-mass movements take to place an intensive warm and moist air-mass. Associated with that, there're presences of the condensing nuclei into a cyclonic pattern. Those characteristics are the ideal ingredients for 
convective processes. At all of those facts, it's added the orographic effects who driven at an abundance of convective cells with the orographic initiation. The gradual approximation of a cold atmospherically front conducts at the occurrence of multi-cells clouds without the change of wind's direction. On the satellite pictures, by especially on the RADAR products, those cells will be distinguished as a line of cells, like a long chain. Those types of cells are more comfortable to follow, and the influences over them are more efficiently.

It should be noted that in most cases based on north-westerly, westerly, and partially, south-westerly air-mass movements, once with the cold front's occurrence, appear the super cellular clods with a deviation of the wind direction. Those are hard to keep under control because the parameters are very high (reflectivity; hail's dimensions; wind shear, VIL).

Therefore, for all of those shown, it was wished to highlight the average dimensions of hail who reached the ground between 2000 and 2018 time intervals associated with the air-mass movements' pattern.

As a result of the atmospherically dynamic correlation with the hail's dimension at the ground, we can conclude the fact that the most significant sizes of hail (over $16 \mathrm{~mm}$ ) recorded during westerly and north-westerly air-mass movement into the anti-cyclonic pattern (NVA, fig.3).

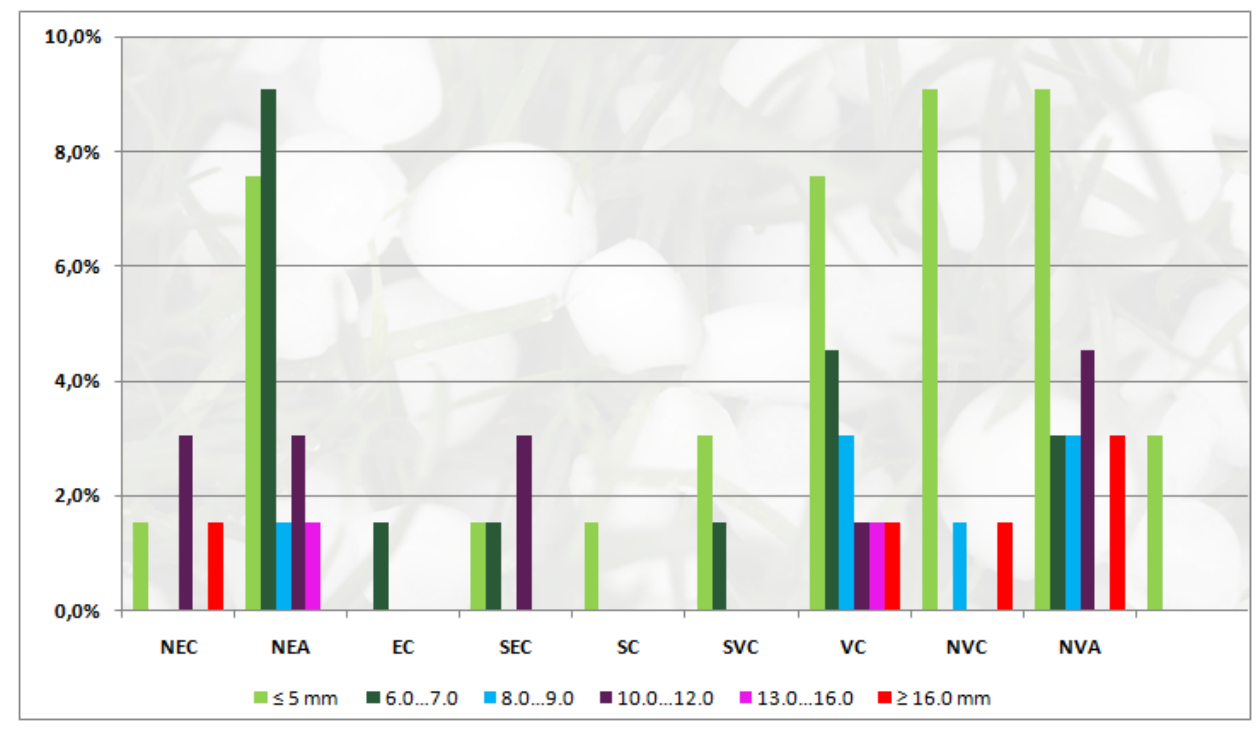

Fig. 3. Frequency of air-mass movement at the level of Moldova from 2000 to 2018 and hail's dimensions associated

The north-westerly air-mass movements into the anticyclonic pattern (NVA) are those situations when at the ground take place, a notable increase of the atmospherical pressure. At the same times, in the high part of the troposphere carry on to be present cut-off lows (Dobri et al., 2017). 
On the opposite side, associated with the eastern and south-eastern air-mass movements, are the smallest sizes of hail that occur at the ground. Moreover, the tiny values of those movements (around 2\%), the dimensions of hail at the ground are at most 5 to $7 \mathrm{~mm}$. This aspect is associated with the fact that the cloudiness systems belong by the same air-mass. This air-mass is one warm, where the isotherm of $0^{\circ} \mathrm{C}$ is very high, over 3700 to $4000 \mathrm{~m}$ altitude. In those conditions illustrated the sector where the melting area of hail is big enough. In the same way, it's happened with the eastern and north-eastern air-mass movements, especially during June. Then toward Moldova is brought a humid and warm air-mass from Pre-Caspian Plain.

In all of those cases, we take into account those convective systems enabled into the same warm air-mass. We associated with these scenarios, small sizes of hail, which, by many times, didn't reach the ground.

In the end, of interest are those types of atmospherical movements from northeastern into anti-cyclonic (NEA) or at the limit of the cyclonic pattern (NEC). In these cases, we talk about those cut-off lows depressions, removed from lowatmospherically areas from the northern part of Europe. Subsequently, those lowpressure areas enabled into an anti-cyclonic area. On these conditions, based upon a mostly clear sky until noon, the air gets warm, and in the afternoon, hours will be conditions for convective cells' development.

The warm air will interact with that cold associated with cold and unstable cores of air. As a result, in the afternoon hours will appear the locally convective clouds, with a random movement, being associated with multi-cells, but into the same type of air-mass. In this case, the following of cells is hard because they have the compatibility of developing spontaneously, from an embryonic stage to one who generates hail fall in just a few minutes.

Most often in the north-eastern air-mass movements into an anti-cyclonic pattern is transported a dry and cold air-mass from vast areas of the Russian Plain. So, the air's humidity is low, and the convective clouds don't contain an essential volume of moisture. Moreover, in such circumstances, don't be those convective cells to meet the maximum point of the convection, reaching the locally limit of the troposphere. In other words, in such synoptic conditions are developing at most the towering cumulus $(\mathrm{Cu} \mathrm{Con})$ or Cumulonimbus calvus $(\mathrm{Cb}$ cal).

Often the hail's sizes that can reach the ground are small. Although the hail's sizes are small and the maximum of reflectivity into the cloud is situated at low heights, because the melting area is thin (the height of $0^{\circ} \mathrm{C}$ placed at 2500 to 2900 $\mathrm{m}$ ), small fragments of hail reach the ground. Moreover, in such weather patterns shown, the air temperature isn't too high into the melting area of hail. Such as the situation took place on May 27th, 2017. Then cloudiness systems with variable movements and dimensions have covered the sky in most of Moldova. In such conditions were difficult to monitor and to seeding over those cells at the Hail Suppress Unit 'Moldova 1' Iași.

Of paramount importance is the fact to highlight those types of atmospherical movements at a particular level, based upon the weather stations (fig.4). It could be 
observed at the general level (at the regional scale); the situation keeps the same features at this level.

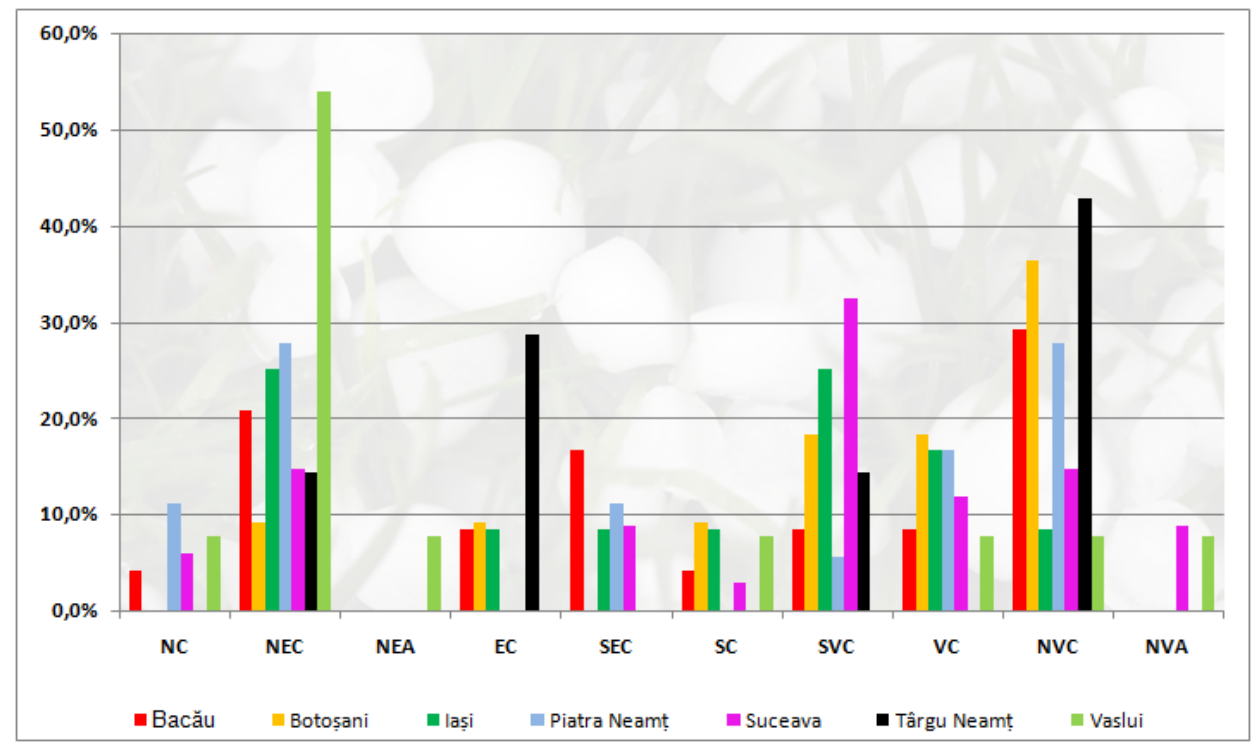

Fig. 4. Frequency of air-mass movement at the level of Moldova on the weather stations and the hail's dimensions recorded between 2000 and 2018

Thus, all the north-eastern, north-western, south-western, and westerly air-mass movements show a significant weight. Following this chart, for the Vaslui area, a considerable influence is owned by eastern air-mass actions, with over $50 \%$. Also, for the rest of the monitoring points, the weight swings around $20 \%$. It's noticed the fact that as it advanced toward the south, the north-eastern, even eastern airmass movements, both into the cyclonic pattern, get to increase. This fact is due precisely to low-depression influences that have a retrogressive tendency.

Also, significant weights own the north-westerly air-mass movements, with values placed around 8 to $10 \%$ for the eastern and south-eastern side of Moldova, and values around 28 to $37 \%$ for the observation points near of the Carpathian range. Moreover, at Târgu Neamt, that values increase to $42 \%$. These cities' place gives that uneven spread of the north-westerly air-mass movements at the Moldova level following the primary vector of atmospherical movement. For Botoșani and Suceava, besides the fact that they placed in the northern part of Romania, an important point is the 'Coandă effect.' This phenomenon drives the westerly airmass movements into ones from north-westerly toward south-eastern. As a result, the colder air-mass, by oceanic origins, crosses the North Europe Plain and then, due to the 'Coandă effect,' is driven toward Moldova where replaces a warm and moist air-mass. Because of that replacement over Moldova, especially in her northern sector, take place strong convective processes (Bordei-Ion N., 1988, taken by Apostol, Sfîcă, 2013). 
High weights are in the case of south-westerly air-mass movements into the cyclonic pattern (SVC), with approximately $33 \%$ for Suceava, $27 \%$ for Iași, or $19.5 \%$ for Botoșani. All of those air-mass movements can generate those convective developments into the same air-mass. When those air-masses cross the Carpathian Range are conditions for convective clouds with orographic development. As the weather stations are closer by Carpathian Range, the frequency of such events will show higher values and vice versa.

To illustrate the one shown previously, by importance is the following map where is shown evidence of the air-mass movements who were associated with hail, which reached the ground (fig.5). Near of the Carpathian Range, where the orographic developments are more prominent, it can be noticed a clear presence of the westerly air-mass advections, with its subdivisions: north-westerly and south-westerly.

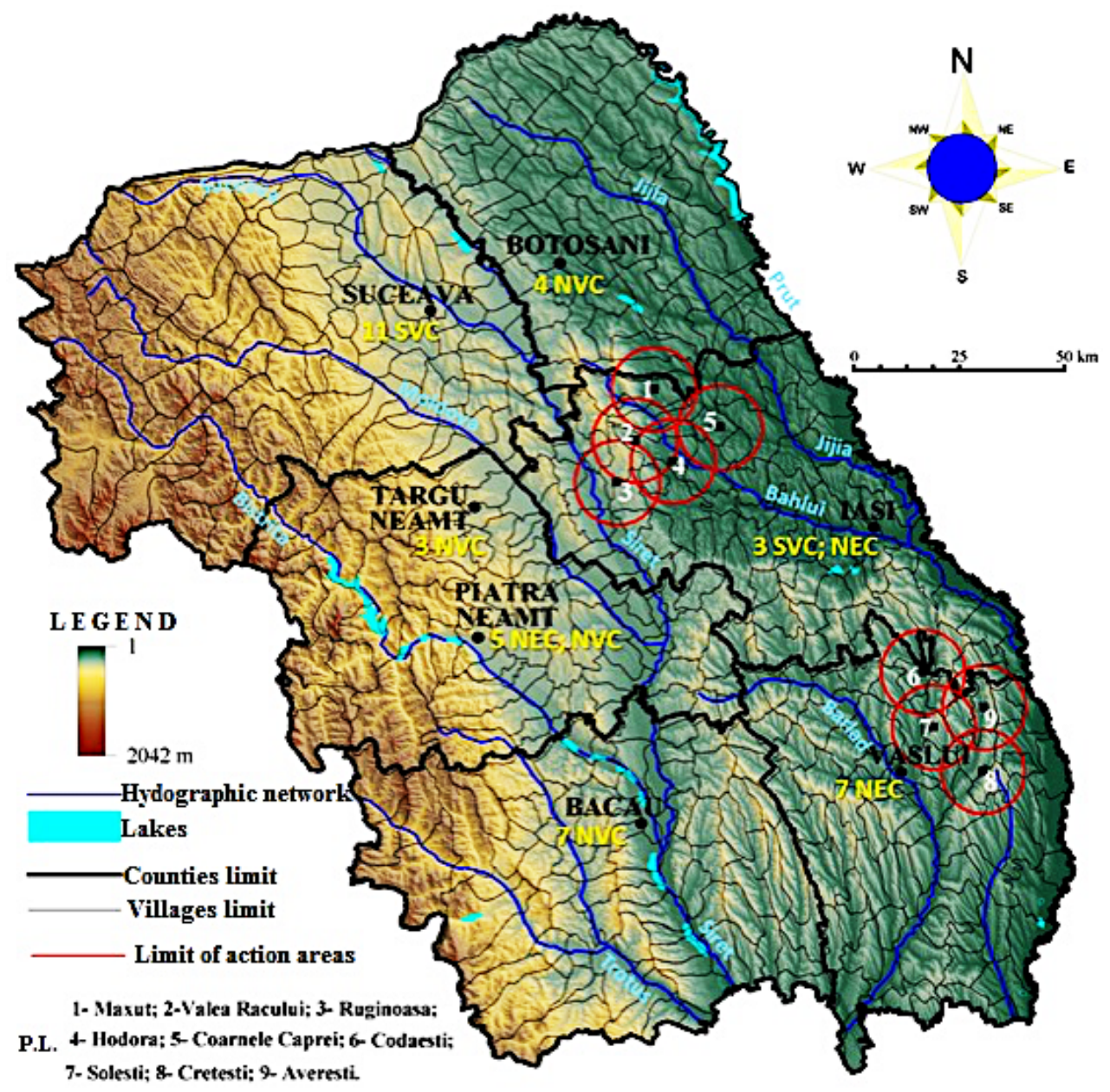

Fig. 5. Representative cases with atmospheric circulation which generated hail at Moldova's level between 2000 and 2018; P.L. - LAUNCHING POINT 
For Suceava, the most representative is the south-westerly air-mass movements into the cyclonic regime. In all periods, this direction owned 11 cases. This situation is given by those south-westerly air-mass movements merged with the far south part of the Maramureș - Bucovina mountain range, but especially by the Central range of the Eastern Carpathian. Associated with those mountains are the peaks which reach and exceed $2000 \mathrm{~m}$, but a high rate of fragmentation. That high rate of fragmentation represents a good incentive for orographic developments because the lowlands, such as depression and valley, get very warm. This warming represents an important step in the convective clouds' growth in the afternoon. Moreover, the mountain peaks disturb the main flow, which comes from west and south-westerly, a fact that favors the increase rate of convective clouds' development.

Also, this pattern show at Suceava is valuable for the rest of the monitoring points placed near the Carpathian range. Therefore, at Târgu Neamț are recorded three cases, Piatra Neamț with five cases, even with those from north-eastern into the cyclonic pattern (NEC), and seven cases with north-western air-mass movements at Bacău.

For the northern part of Moldova, more accurate, over the Jijia Plain, were recorded four cases with north-westerly in the cyclonic pattern at Botoșani. Here, the primary vector is the deviation of the westerly air-mass movements. As a result, in more situations, once the cold air-mass got here, take place violent weather patterns, where the cold air-mass replaces one warm and moist. In such circumstances, besides other severe weather events were recorded large sizes of hail ( 15 to $25 \mathrm{~mm}$ ) who reach the ground.

The analyze made over the south and south-westerly side of the Botoșani County, south-eastern side of Suceava County, and eastern side of Neamț County is more important as all of those counties are bordering whit Hail Suppress Group of Cotnari (placed into Iași County). In doing so, the westerly and north-westerly airmass movements bring the most dangerous storms, and the Cotnari area is exposed directly to all of these storms. Moreover, at the west of Cotnari are placed the Siret River and the vast regions with forests. All of those work by many times as a spur of hail's development. Also, the Cotnari Group is directly exposed to northern airmass movements, because the Moldova Plain has a lot of lakes, especially over Botoșani County. Worthy of highlighting the hydro-technical build over Prut River, placed in Ștefănești village, the eastern side of the Botoșani County. This dam is the second largest of that kind after that from the Iron Gates (south-western part of Romania, the Danube River).

Once with the advance toward south and south-east, the air-mass movements' weight that generates hail is changed, being a most representative from that from north-eastern into the cyclonic pattern (NEC). For example, in Vaslui, we had seven cases with NEC from 2000 to 2018 time period. The feature is given by the fact that the eastern part of Moldova is placed at a visible distance by the Carpathian range. Moreover, in this part of Moldova, more important are the south-eastern air-mass movements, all of those associated with the retrogressive low-depression. 
For the monitoring point of Iași, a significant role is played by north-eastern and north-westerly movement, both of them into a cyclonic pattern. Therefore, Iași being situated at the contact represented between two major physical-geographical units, namely: the Moldova Plain (at north-western) and the Central Moldavian Tableland (at the south), occur that alternates between those recalled previously. All the airmass movements from the north show the same features illustrated in Botoșani case.

By importance for the present study is to show the maximum sizes of hail reaching the ground in the entire period of reference. According to the map attached (fig. 6), the most significant sizes of hail who reached the earth were at Piatra Neamt with $25 \mathrm{~mm}$ on June, $18^{\text {th }}$, 2016. Instead, the lowest values are valuable for Bacău and Botoșani, with approximately seven $\mathrm{mm}$.

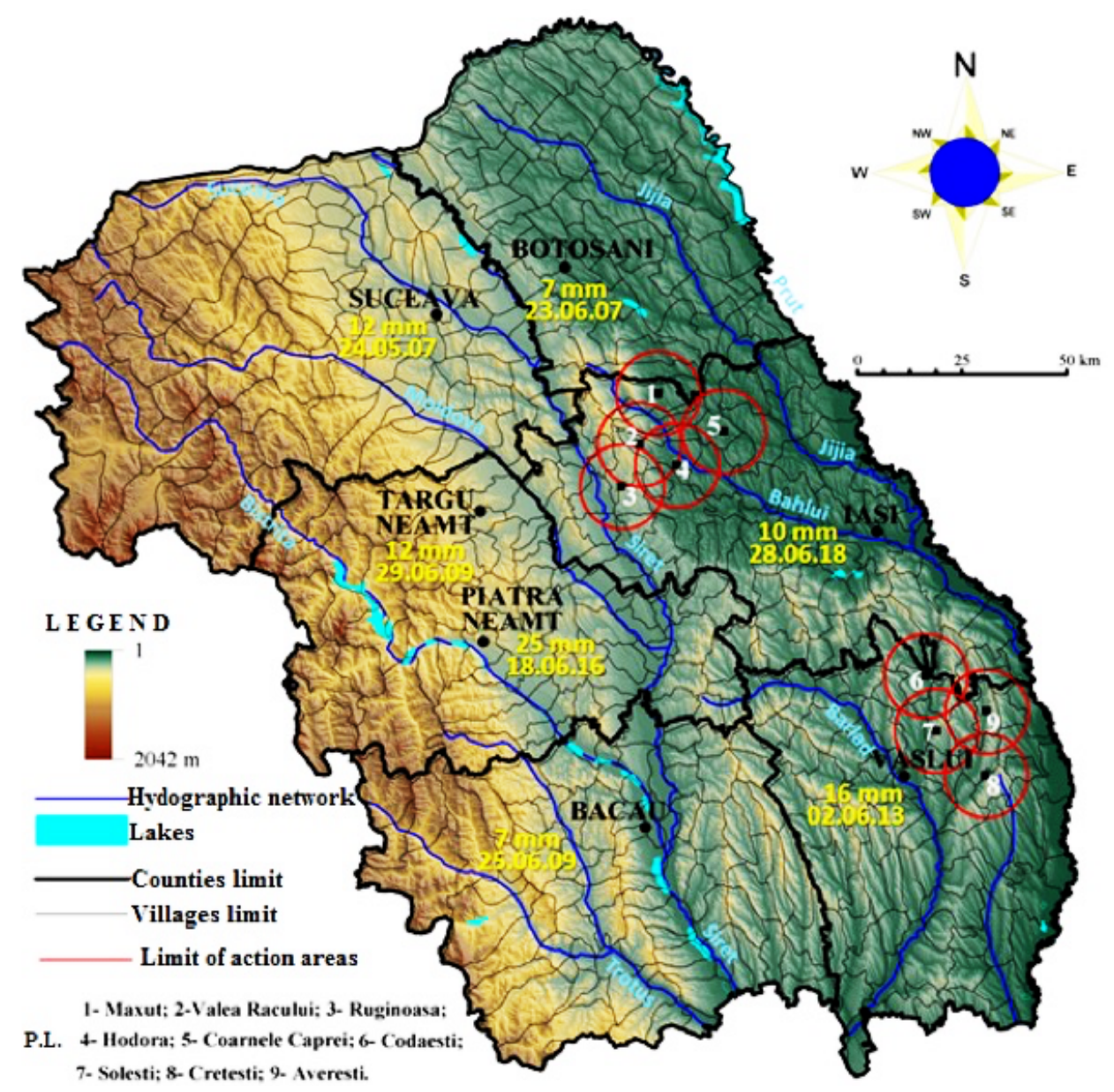

Fig. 6. The maximum dimensions of hail who reached the ground at the Moldova level between 2000 and 2018; P.L. - LAUNCHING POINT 
The hail is associated exclusively with convective processes, as a result of orographic development in the same air-mass or into the squalls lines, being very hard to monitories (Istrate et al., 2016). More accurate, due to the randomly features of the convective cloudiness systems, merged with the melting area, and the wind shears can be reported hail at the ground at 500 meters away from a weather station. That's way at a namely weather station can't be reported hail falls while in at 1000 meters away, the hail can show sizes around $10 \mathrm{~mm}$ or more, with disruptive potential.

Furthermore, the rainfall associated with the convective clouds shows a confined area where they are present, opposite with the precipitations, which are associated with the mid-level clouds, such as Nimbostratus $(\mathrm{Nb})$. Thereby, all the rainfall associated with the mid-level clouds lasts 12 to 24 hours and can be easy to follow.

\section{CONCLUSIONS}

This study highlighted the types of the atmospherical movements which generate hail falls with disruptive potential. Based upon the thermodynamically features illustrated, the most significant sizes of hail falls $(40$ to $60 \mathrm{~mm}$ ) are associated with the north-westerly and westerly air-mass movements, both of them into the cyclonic pattern. Also, it can be noticed the occurrence of anti-cyclonic pattern in the case of north-westerly, those when taking place progressive increase of the atmospherical pressure and replaced the previously warm and moist air-mass.

Also, it wanted an exposing of all the atmospherically movements with the type of the convective process associated. In the case of the eastern air-mass advection, by importance are the significant amounts of precipitations than the hail occurrence. Obviously, and in this case, we can take into account the appearance of hail, but it presents small dimensions. As a result, in many cases, this doesn't reach the ground level.

In the future, we want to continue this study regarding the hail's climatology at Moldova's level and the role played by Hail Suppress Unite 'Moldova 1' Iași in this field. Besides the data gathered in the terrain, from the weather station network, by importance will be the RADAR data and a network of hail pads. Once the hail pads network implemented, we can make a more uniform study about the hail. Also, with the aid of those products, there will determine other indicators on this field of the hail.

\section{ACKNOWLEDGEMENTS}

This work was co-funded by the European Social Fund, through Operational Programme Human Capital 2014-2020; project number POCU/380/6/13/123623, project title 'PhD Students and Postdoctoral Researchers Prepared for the Labor Market' 


\section{REFERENCES}

1. Apostol L., Machidon O. (2009) - Consideraţii asupra fenomenului de grindină în bazinul hidrografic Bârlad. Analele ştiințifice ale Universității. "Ştefan cel Mare" Suceava, secţiunea Geografie, 18, 61-72 .

2. ***, Sfî̀ă L. (2013) - Thermal differentiations induced by the Carpathian Mountains on the Romanian territory. Carp J Earth Environ Sci 8(2), 215-221.

3. Bordei-Ion N. (1988) - Fenomene meteoclimatice induse de configurația Carpaților în Câmpia Română, Ed. Academiei Române, București, România, p.224.

4. Botzen W.J.W., Bouwer L., van den Bergh J. (2010). Climate change and hailstorm damage: Empirical evidence and implications for agriculture and insurance.

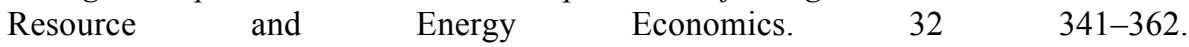
https://www.sciencedirect.com/science/article/abs/pii/S0928765509000517

5. Brimelow J.C., Burrows W.R., Hanesiak J.M. (2017). The changing hail threat over North America in response to anthropogenic climate change. Nature Climate Change. 7(7): 516-523. https://www.nature.com/articles/nclimate3321

6. Dobri R.-V., Sfîcă L., Ichim P., Harpa G.-V. (2017) - The distribution of the monthly 24-hour maximum amount of precipitation in Romania according to heir synoptic causes. Geographia Technica, Cluj-Napoca. 12 (2) 62 to 72. https://DOI: 1021163/GT 2017.122.06

7. Changnon S.A., Farhar B.C., Swanson E.R. (1978). Hail Suppression and Society: Assessment of future hail suppression technology reveals its development should be sizable or ignored. Science. 200, 387-394. 10.1126/science.200.4340.387. DOI: DOI: $10.1126 /$ science.200.4340.387

8. Cică R., Burcea S., Bojariu R. (2015). Assessment of severe hailstorms and hail risk using weather radar data. Royal Meteorological Society. 22(4): 746-753. DOI: https://doi.org/10.1002/met.1512

9. Fuchs S., Birkmann J., Glade T. (2012). Vulnerability assessment in natural hazard and risk analysis: current approaches and future challenges. Natural Hazards. 64(3): 1969-1975. https://link.springer.com/article/10.1007/s11069-012-0352-9

10. Hoogewind K.A., Baldwin M.E., Trapp R.J. (2017). The Impact of Climate Change on Hazardous Convective Weather in the United States: Insight from HighResolution Dynamical Downscaling. Journal of Climate. 30(24): 10081-10100. DOI: https://doi.org/10.1175/JCLI-D-16-0885.1

11. Istrate V., Axinte A., D., Apostol L., Florea D., Machidon O., M. (2016). The efficacity of hail supression in Iasi County (Romania) - Case study: July 9th, 2015. 16th International Multidisciplinary Scientific GeoConference SGEM, Bulgary. 1081-1088.

12. National Meteorological Administration. (2008). The climate of Romania. Editura Academiei Române, Bucharest, Romania; 368 pp. (in Romanian). ISBN: 978-973-27-1674-8.

13. Sfîcă L., Niță A., Iordache I., Ilie N. (2016). Specific weather conditions on Romanian territory for Hess-Brezowsky westerly circulation type. 15th International Multidisciplinary Scientific GeoConference SGEM, Bulgary, 1073-1080.

14. Velten S., Leventon J., Jager N., Newig J. (2015). What Is Sustainable Agriculture? A Systematic Review. Sustainability. 7, 7833-7865. https://www.mdpi.com/20711050/7/6/7833/htm

15. Zhao J.T., Yue Y.J., Wang J.A., Yin Y.Y., Feng H.Y. (2015). Study on Spatiotemporal Pattern of Hail Disaster in China Mainland from 1950 to 2009. Chinese Journal of Agrometeorology. 36(1): 83-92. (in Chinese with English abstract). 